Kong. Res. J. 2(1) : 138-140, 2015

ISSN 2349-2694

Kongunadu Arts and Science College, Coimbatore.

\title{
THE JOURNAL OF ENTREPRENEURSHIP- A BIBLIOMETRIC STUDY
}

\author{
Senthilkumar, $\mathbf{R}^{1^{*}}$. and G. Ulaganathan ${ }^{2}$ \\ ${ }^{1}$ Department of Library and Information Science, Kongunadu Arts \& Science College (Autonomous), \\ Coimbatore. \\ 2Department of Library and Information Science, Dr.SNS.Rajalakshmi College of Arts \& Science, Coimbatore. \\ *E.mail: kasclibrary@yahoo.com
}

\begin{abstract}
This paper presents a bibliometric analysis of the journal "The Journal of Entrepreneurship" for the period between 2007 to 2013.The analysis cover mainly the distribution of articles volume wise, Year wise authorship pattern, geographical distribution of articles, distribution of citations, forms of documents cited, length of issues length of articles. All the studies point towards the merits and weakness of the journal which will be helpful for its further development. The study reveals that journals accounted highest number of journal citation with 1525 (51.87\%) Followed by books with 798 (27.14\%) and Seminar/conference Proceedings /Thesis sources 233(7.93\%) Citations ,Reports 221(7.52\%) citations, and Web sites with163(5.54\%) citations it was seen that the majority of the authors use mostly journal articles for their article publications.
\end{abstract}

Key words: Bibliometrics, Bibliography, Citation analysis, Authorship pattern, Geographical distribution.

\section{INTRODUCTION}

Bibliometric analysis is the quantitative description of literature and helps in the measurement of the patterns of all forms of recorded information and their producers. It has extensive applications in the field of library and information science particularly with regards to studying the trends in a particular subject. The subject of bibliometrics was first defined by Pritchard (1969) as "the application of mathematical and statistical methods to books and other media". It involves the analysis of a set of publications characterized by bibliographic variables such as the author(s), the subject keywords and the citations. The methods of Bibliometrics (and the closely related specialism of informatics, Scientometrics and Webometrics (Hood and Wilson 2001) are used to investigate an increasing range of topics. According to Sengupta (1985) Bibliometrics is the organization classification and quantitative evaluation of publication patterns of all macro and micro communication along with their authorships by mathematical and statistical calculus. The British standard Institution (1976) defines that the word bibliometric is used to study of documents and patterns of publications in which mathematical and methods have been applied.

The current study is a bibliometric analysis of the journal "The Journal of Entrepreneurship "for the period 2007 to 2013. The Journal of Entrepreneurship is a multidisciplinary forum for the publication of articles and research and discussion of issues that bear upon and enfold the field of entrepreneurship. Topics appropriate and related to entrepreneurship include intrapreneurship, manager ship, organizational behavior, leadership, motivation, training and ethical / moral notions guiding entrepreneurial behavior. Disciplinary boundaries that straddle entrepreneurship theory and research include economics, psychology, sociology, anthropology, history, management and others. The journal of entrepreneurship is peer-reviewed Journal with ISSN 0971-3557. The journal is published by SAGE publications, Los Angeless, London, New Delhi, Singapore and Washington DC -in March and September. In this study, the articles published during the period 2007 to 2013(7 Year Issues) have been analyzed.

\section{METHODOLOGY}

Seven volumes (volume 16to 22 each 2 issues) containing 12 issues of The Journal of Entrepreneurship Published during the year 2007 2013 have been taken up for the study. The details with regard to each published article such as distribution of articles volume-wise, year wise authorship pattern, year wise geographical distribution of articles by authors, year wise distribution of citations, Forms of documents cited, length of issues, length of articles were recorded and analyzed for making observations. 
Table 1. Distribution of articles volume-wise (Volume number 16-22)

\begin{tabular}{cccccccccc}
\hline Month & $\mathbf{1 6}$ & $\mathbf{1 7}$ & $\mathbf{1 8}$ & $\mathbf{1 9}$ & $\mathbf{2 0}$ & $\mathbf{2 1}$ & $\mathbf{2 2}$ & $\begin{array}{c}\text { Total } \\
\text { volume } \\
\text { wise \% }\end{array}$ \\
\hline March & 10 & 9 & 10 & 8 & 9 & 9 & 10 & 65 & 48.51 \\
September & 9 & 10 & 9 & 12 & 10 & 10 & 9 & 69 & 51.49 \\
Total & 19 & 19 & 19 & 20 & 19 & 19 & 19 & 134 & 100 \\
\hline Volume Wise $\%$ & 14.18 & 14.18 & 14.18 & 14.92 & 14.18 & 14.18 & 14.18 & 100.00 & 100 \\
\hline
\end{tabular}

The table 1 reveals distribution of articles (volume -wise). Volume number 19 shows the highest number of total articles 20 published. The other volumes are same number of publications 19 articles.

Table 2. Year wise authorship pattern

\begin{tabular}{|c|c|c|c|c|c|c|c|c|c|}
\hline Authorship & 2007 & 2008 & 2009 & $\begin{array}{r}\text { Year } \\
2010\end{array}$ & 2011 & 2012 & 2013 & Total & Percentage \\
\hline Single & 14 & 14 & 10 & 16 & 12 & 13 & 10 & 89 & 66.42 \\
\hline Joint & 5 & 5 & 9 & 4 & 7 & 6 & 9 & 45 & 33.58 \\
\hline Total & 19 & 19 & 19 & 20 & 19 & 19 & 19 & 134 & 100.00 \\
\hline
\end{tabular}

The above Table - Showed that out of 134 articles single author 89(66.42\%) articles while the 45 (33.58\%) articles were contributed by joint authors.

Table 3. Year wise geographical distribution of articles by authors

\begin{tabular}{|c|c|c|c|c|c|c|}
\hline Year & Indian & Percentage & Foreign & Percentage & Total & percentage \\
\hline 2007 & 11 & 5.53 & 16 & 8.04 & 27 & 13.57 \\
\hline 2008 & 13 & 6.53 & 13 & 6.53 & 26 & 13.06 \\
\hline 2009 & 21 & 10.55 & 9 & 4.52 & 30 & 15.07 \\
\hline 2010 & 13 & 6.53 & 12 & 6.03 & 25 & 12.56 \\
\hline 2011 & 11 & 5.53 & 19 & 9.55 & 30 & 15.08 \\
\hline 2012 & 7 & 3.52 & 23 & 11.56 & 30 & 15.08 \\
\hline 2013 & 14 & 7.04 & 17 & 8.54 & 31 & 15.58 \\
\hline Total & 90 & 45.23 & 109 & 54.77 & 199 & 100.00 \\
\hline
\end{tabular}

Table 3 showed that maximum number of articles by authors in the year 2013 articles 31 (15.58\%) followed by the year 2009, 2011, 2012 number of articles 30 each (15.08\%) and the year2010 minimum number of articles25 (12.56\%).

Table 4. Year wise distribution of citations

\begin{tabular}{ccc}
\hline Year & Number of Citations & Percentage \\
\hline 2007 & 393 & 13.37 \\
2008 & 243 & 8.27 \\
2009 & 327 & 11.12 \\
2010 & 332 & 29.58 \\
2011 & 605 & 18.50 \\
2012 & 544 & 16.87 \\
2013 & 496 & 100.00 \\
\hline
\end{tabular}

The above Table 4 showed that maximum number of citations 605(20.58\%) produced as 2011 followed by 544 (18.50\%) citations in 2012 and 496(16.87\%) in the year 2013.

Table 5. Forms of documents cited

\begin{tabular}{ccc}
\hline Forms of Document & Total Number of citation & Percentage \\
\hline Journals & 1525 & 51.87 \\
Books & 798 & 27.14 \\
Seminar/ & 233 & 7.93 \\
Conference Proceedings /Thesis & 221 & 7.52 \\
Reports & 163 & 5.54 \\
Websites & 2940 & 100 \\
\hline Total &
\end{tabular}

The table 5 above showed that majority of the contributors preferred journals as the source of information which occupied the top position with the highest number of citations 1525 (51.87\%) of the 2940 total citations followed by books with $798(27.14 \%)$ citations, Seminar/Conference Proceedings/ Thesis sources 233(7.93\%) citations, Reports 221(7.52\%) citations, and Websites with163(5.54\%) citations. It is found that 
the researchers preferred journal articles more frequently for their research work, than any other types of communication channels.

Table 6. Distribution length of issues year-wise

\begin{tabular}{cccccccccc}
\hline $\begin{array}{c}\text { Year/ } \\
\text { Month }\end{array}$ & $\mathbf{2 0 0 7}$ & $\mathbf{2 0 0 8}$ & $\mathbf{2 0 0 9}$ & $\mathbf{2 0 1 0}$ & $\mathbf{2 0 1 1}$ & $\mathbf{2 0 1 2}$ & $\mathbf{2 0 1 3}$ & Total & Issue wise \% \\
\hline March & 130 & 101 & 137 & 98 & 158 & 171 & 133 & 928 & 51.58 \\
September & 100 & 103 & 102 & 145 & 144 & 156 & 121 & 871 & 48.42 \\
Total & 230 & 204 & 239 & 243 & 302 & 327 & 254 & 1799 & 100 \\
$\begin{array}{c}\text { Year } \\
\text { Wise } \%\end{array}$ & 12.78 & 11.34 & 13.29 & 13.51 & 16.78 & 18.18 & 14.12 & 100 & \\
\hline
\end{tabular}

The above table 6 shows that highest number of 327(18.18\%) pages was published during the year 2012 followed by the years 2011 number of pages 302 (16.78\%) and 2013 with 254(14.12\%) pages.

Table 7. Length of articles

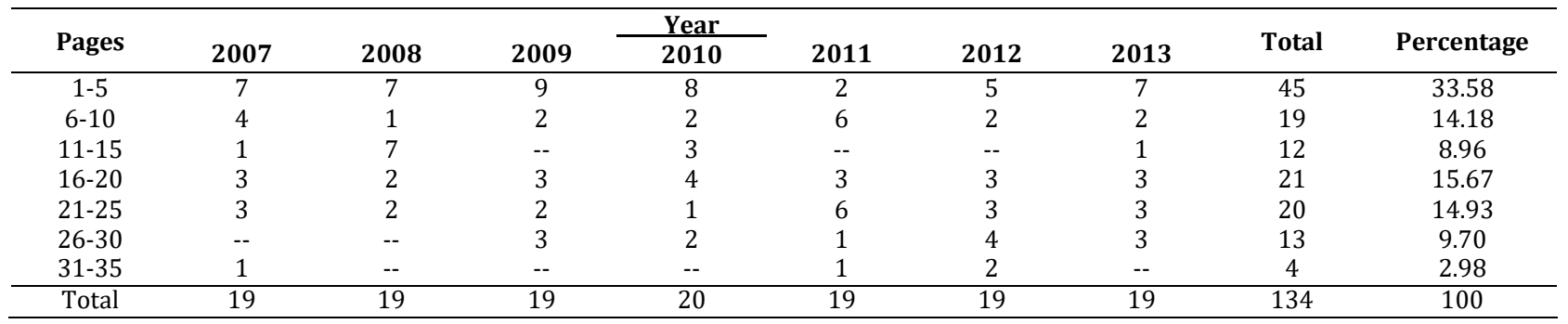

The table7 reveals that the majority of articles $45(33.58 \%)$ have the length of $1-5$ pages followed by $21(15.67 \%)$ articles with $16-20$ pages,20(14.93\%) articles with $21-25$ pages, $19(14.18 \%)$ articles $6-10$ pages,13(9.70\%) articles $26-30$ pages,12(8.96\%) articles $11-15$ pages and remaining $4(2.98 \%)$ articles have the length 31-35 pages.

\section{CONCLUSION}

Bibliometric techniques are being used for a variety of purposes like determination of various scientific indicators, evaluation of scientific output, selection of journals for libraries and even forecasting the potential of a particular field. The popularity in the adaptation of bibliometric techniques in various disciplines stimulated stupendous growth of literature of bibliometrics and its areas. The journal has published 134 articles during the period of study. The maximum number of contributions is single authors with $89(66.42 \%)$. The present study reveals that the most of the articles are published by Academic profession authors $190(95.48 \%)$. The most of the contributors are from Foreign with $54.77 \% \%$ while Indian contributions are $45.23 \%$ only. The study revealed that the highest contributions were from universities with
$110(55.28 \%)$. Majority of the authors preferred journals $1525(51.87 \%)$ as the source of information.

\section{REFERENCES}

Pritchard Alan, (1959). A Statistical Bibliography: An Interim Bibiliography. North-western Polytechnic School of Librarianship, London.

Hood and C.S. Wilson, (2001). Annual Review of Information Science and Technology. 34: 3143.

Sengupta, I.N., (1985). Bibliometrics, Informetrics, Scientometrics and Libraries: An overview Libri: International Library Review. 42(2): 7598.

British Standards Institution, (1976). British standards of documentation terms. BSI; London. p7. 